\title{
Structural studies on encapsulation of tetrahedral and octahedral anions by a protonated octaaminocryptand cage
}

\author{
I. Ravikumar ${ }^{1}$, P. S. Lakshminarayanan ${ }^{1}$, E. Suresh ${ }^{*}, 2$ and Pradyut Ghosh ${ }^{*}, 1$
}

\section{Full Research Paper}

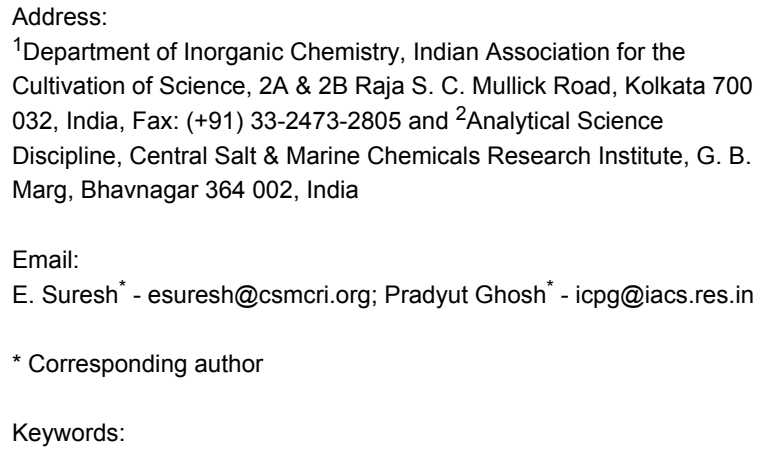

Beilstein Journal of Organic Chemistry 2009, 5, No. 41. doi:10.3762/bjoc.5.41

Received: 22 April 2009

Accepted: 27 August 2009

Published: 31 August 2009

Editor-in-Chief: J. Clayden

(c) 2009 Ravikumar et al; licensee Beilstein-Institut. License and terms: see end of document.

\begin{abstract}
Structural aspects of the binding of inorganic anions such as perchlorate, hydrogen sulfate, and hexafluorosilicate with the proton cage of octaaminocryptand $\left.\mathbf{L}^{\mathbf{1}}, \mathrm{N}\left(\mathrm{CH}_{2} \mathrm{CH}_{2} \mathrm{NHCH}_{2}-p \text {-xylyl- } \mathrm{CH}_{2} \mathrm{NHCH}_{2} \mathrm{CH}_{2}\right)_{3} \mathrm{~N}\right)$, are examined thoroughly. Crystallographic results for a hexaprotonated perchlorate complex of $\mathbf{L}^{1},\left[\left(\mathrm{H}_{6} \mathrm{~L}^{1}\right)^{6+}\left(\mathrm{ClO}_{4}^{-}\right)\right] 5\left(\mathrm{ClO}_{4}^{-}\right) \cdot 11 \mathrm{H}_{2} \mathrm{O} \cdot \mathrm{CH}_{3} \mathrm{CN}(\mathbf{1})$, an octaprotonated hydrogen sulfate complex of $\mathbf{L}^{1}$, $\left[\left(\mathrm{H}_{8} \mathbf{L}^{1}\right)^{8+}\left(\mathrm{HSO}_{4}^{-}\right)\right] 7\left(\mathrm{HSO}_{4}^{-}\right) \cdot 3 \mathrm{H}_{2} \mathrm{O} \cdot \mathrm{CH}_{3} \mathrm{OH}(\mathbf{2})$ and an octaprotonated fluorosilicate complex of $\mathbf{L}^{\mathbf{1}},\left[\left(\mathrm{H}_{8} \mathbf{L}^{1}\right)^{8+}\left(\mathrm{HSiF}_{6}{ }^{-}\right)\right] 3\left(\mathrm{SiF}_{6}{ }^{2-}\right) \cdot\left(\mathrm{HSiF}_{6}{ }^{-}\right) \cdot 15 \mathrm{H}_{2} \mathrm{O}(\mathbf{3})$, show encapsulation of one perchlorate, hydrogen sulfate and hexafluorosilicate, respectively inside the cage of $\mathbf{L}^{\mathbf{1}}$ in their protonated states. Further, detailed structural analysis on complex $\mathbf{1}$ reveals that the hexaprotonated $\mathbf{L}^{1}$ encapsulates a perchlorate via two $\mathrm{N}-\mathrm{H} \cdots \mathrm{O}$ and five $\mathrm{O}-\mathrm{H} \cdots \mathrm{O}$ hydrogen bonds from protonated secondary nitrogen atoms of $\mathbf{L}^{\mathbf{1}}$ and lattice water molecules, respectively. Encapsulated hydrogen sulfate in complex $\mathbf{2}$ is "glued" inside the octaprotonated cage of $\mathbf{L}^{1}$ via four $\mathrm{N}-\mathrm{H} \cdots \mathrm{O}$ and six $\mathrm{C}-\mathrm{H} \cdots \mathrm{O}$ hydrogen bonds whereas encapsulated $\mathrm{HSiF}_{6}{ }^{-}$in complex $\mathbf{3}$ has short contacts via six $\mathrm{N}-\mathrm{H} \cdots \mathrm{F}$ and three $\mathrm{C}-\mathrm{H} \cdots \mathrm{F}$ hydrogen bonds with $\left[\mathrm{H}_{8} \mathbf{L}^{1}\right]^{8+}$. In the cases of complexes $\mathbf{2}$ and $\mathbf{3}$, the cryptand $\mathbf{L}^{\mathbf{1}}$ in octaprotonated state shows monotopic encapsulation of the guest and the final conformation of these receptors is spherical in nature compared to the elongated shape of hexaprotonated state of $\mathbf{L}^{\mathbf{1}}$ in complex $\mathbf{1}$.
\end{abstract}

\section{Introduction}

In recent years considerable efforts have been made in elucidating the coordination chemistry of anions because of their vital roles in biological systems [1], medicine [2], catalysis [3], and environmental issues [4]. Perchlorate is harmful to human health and has applications in defense [5], commercial and domestic purposes [6], whereas sulfate recognition is of current interest due to its biological [7] and environmental importance [8]. It has been observed that protonated amines and quaternary 


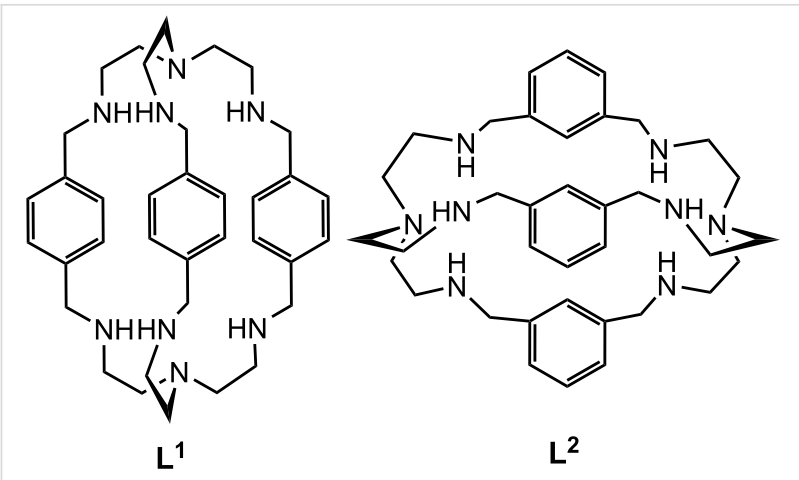

Figure 1: Octaaminocryptand with $p$-xylyl spacers $L^{1}$, with $m$-xylyl spacers $\mathbf{L}^{2}$

ammonium functions incorporated in a suitable ligand topology make them attractive receptors for anions [1-4]. Azamacropolycycles $\mathbf{L}^{\mathbf{1}}$ and $\mathbf{L}^{\mathbf{2}}$ (Figure 1) have shown encapsulation of different anions in their protonated states [9-22]. For example, azamacropolycycle $\mathbf{L}^{\mathbf{1}}$ (Figure 1) forms a fluoride-based cascade complex [9], whilst for chloride/bromide encapsulation inside the cavity of hexaprotonated $\mathbf{L}^{\mathbf{1}},\left[\mathrm{H}_{6} \mathbf{L}^{\mathbf{1}}\right]^{6+}$ leads to both monohydrated complexes [10] and monotopic chloride/bromide complexes [11]. Protonated ligand $\left[\mathrm{H}_{7} \mathbf{L}^{1}\right]^{7+}$ leads to monotopic encapsulation of chloride via hydrogen bonding with external undecameric water clusters [12] whilst iodide encapsulation has been observed in the case of $\left[\mathrm{H}_{8} \mathbf{L}^{\mathbf{1}}\right]^{8+}[13]$. Whereas there are a large number of reports on halide encapsulation in different protonated states for $\mathbf{L}^{\mathbf{1}}$, encapsulation of polyatomic anions such as tetrahedral $\left(\mathrm{ClO}_{4}^{-}, \mathrm{HSO}_{4}^{-}, \mathrm{H}_{2} \mathrm{PO}_{4}^{-}\right)$, and octahedral $\left(\mathrm{SiF}_{6}{ }^{2-}, \mathrm{PF}_{6}{ }^{-}\right)$anions etc. have not been reported with this system, although planar $\left(\mathrm{NO}_{3}{ }^{-}\right)$encapsulation and binding of $\mathrm{H}_{2} \mathrm{PO}_{4}{ }^{-}$by $\left[\mathrm{H}_{6} \mathbf{L}^{1}\right]^{6+}$ have been observed $[14,15]$. By contrast, $\mathbf{L}^{\mathbf{2}}$, as host has been extensively used for oxyanion binding [16-22]. In 1995 the first structurally characterized encapsulated $\mathrm{ClO}_{4}{ }^{-}$and $\mathrm{SiF}_{6}{ }^{2-}$ by hexaprotonated furan and pyridine analogues of $\mathbf{L}^{\mathbf{1}}$, respectively were reported by Nelson et al. [23]. Very recently, Bowman-James et al. have shown encapsulation of sulfate inside the cavity of $\left[\mathrm{H}_{6} \mathbf{L}^{2}\right]^{6+}[24]$. Other organic receptors for perchlorate $[25,26]$ and sulfate [27-32] have been described in the literature. Nelson et al. have reviewed the recognition of oxanions by different azacryptand hosts [33]. Steed et al. have reported a macrobicyclic azaphane receptor for halide binding through $\mathrm{C}-\mathrm{H} \cdots \mathrm{X}^{-}$and $\mathrm{N}-\mathrm{H} \cdots \mathrm{X}^{-}$ interactions [34]. In this article we report solid state structural evidence of encapsulation and binding of tetrahedral oxyanions $\mathrm{ClO}_{4}{ }^{-}$and $\mathrm{HSO}_{4}{ }^{-}$as well as encapsulation of octahedral anion $\mathrm{HSiF}_{6}{ }^{-}$with $\mathbf{L}^{\mathbf{1}}$ in different protonated states.

\section{Results and Discussion}

Syntheses. The cryptand $\mathbf{L}^{\mathbf{1}}$ was prepared on multi-gram scale and in very high yield following the modified literature procedure [13]. The key step in the scaled-up synthesis of this octaazacryptand is the condensation of tris(2-aminoethyl)amine (tren) with terephthaldehyde at $5-10{ }^{\circ} \mathrm{C}$ by the slow addition of a dry methanolic tren solution to the aldehyde also dissolved in dry methanol. Reduction of the resulting Schiff base was achieved using $\mathrm{NaBH}_{4}$. Both higher temperatures $\left(40-50{ }^{\circ} \mathrm{C}\right)$ and fast addition rates lead to mostly polymeric products in the scaled-up synthesis. In the case of $\mathbf{1}$, a white precipitate is obtained after addition of perchloric acid to the methanolic solution of $\mathbf{L}^{\mathbf{1}}$, which after crystallization from acetonitrile/ water $(1: 1 \mathrm{v} / \mathrm{v})$, gave perchlorate encapsulated in a $\left[\mathrm{H}_{6} \mathbf{L}^{\mathbf{1}}\right]^{6+}$ cage. Complex $\mathbf{2}$ is obtained as white solid upon reacting sulfuric acid with $\mathbf{L}^{\mathbf{1}}$ in acetonitrile medium followed by crystallization from water/MeOH (1:1 v/v). Complex 3 is obtained as a white precipitate upon treating the receptor with hydrofluoric acid in methanol followed by crystallization from water. The syntheses of the complexes are all straight forward and, with the exception of complex $\mathbf{3}$, are obtained in high yield.

Description of the Crystal Structure, $\left[\left(\mathrm{H}_{6} \mathbf{L}^{\mathbf{1}}\right)^{6+}\left(\mathrm{ClO}_{4}{ }^{-}\right)\right]\left[5\left(\mathrm{ClO}_{4}{ }^{-}\right) \cdot 11 \mathrm{H}_{2} \mathrm{O} \cdot \mathrm{CH}_{3} \mathrm{CN}\right.$ (1). Hexaprotonated cryptand cage $\left[\mathrm{H}_{6} \mathbf{L}^{\mathbf{1}}\right]^{6+}$ shows encapsulation of one perchlorate ion in the cavity. This represents monotopic recognition of perchlorate whereas five perchlorate counter anions, along with eleven molecules of water and one acetonitrile molecule as solvent of crystallization are present in the lattice. The ORTEP diagram of the hexaprotonated cryptand moiety with the encapsulated perchlorate is shown in Figure 2. Here the

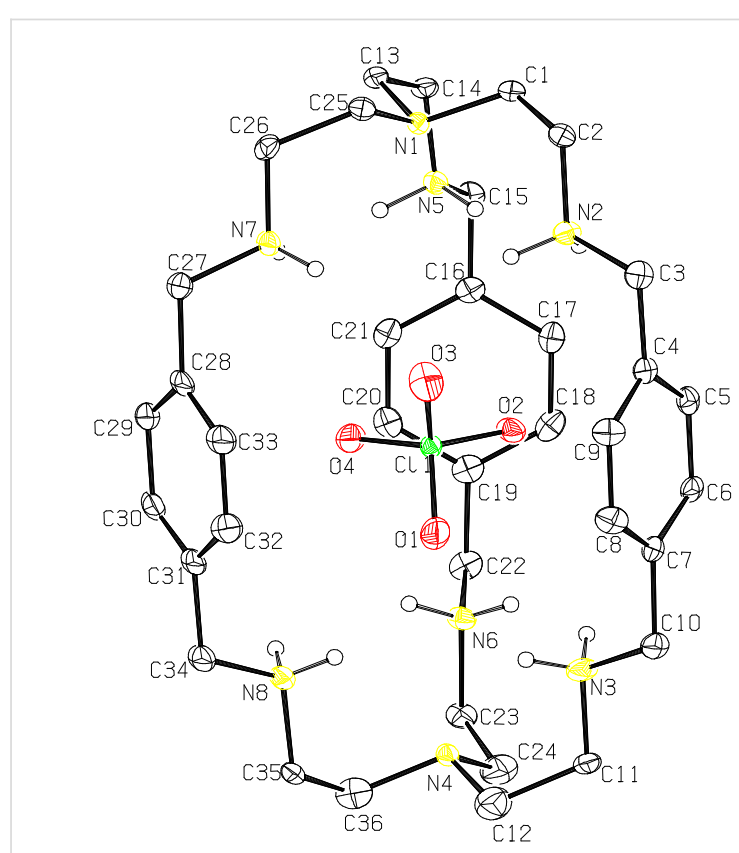

Figure 2: ORTEP diagram of the $\left[\mathrm{H}_{6} \mathrm{~L}^{1}\right]^{6+}$ with encapsulated $\mathrm{ClO}_{4}{ }^{-}$ ( $40 \%$ probability factor for the thermal ellipsoids and hydrogen atoms attached to the protonated nitrogen atoms only are shown for clarity). 
$\left[\mathrm{H}_{6} \mathbf{L}^{\mathbf{1}}\right]^{6+}$ moiety has an endo-endo conformation with a distance of $9.850 \AA$ between the two bridgehead nitrogen atoms $(\mathrm{N} 1$ and $\mathrm{N} 4)$. The window between three phenyl rings ranges from $6.815 \AA$ to $7.126 \AA$ (measured by the centroid of phenyl distance) with an average window of $6.993 \AA$ indicates the elliptical nature of the perchlorate encapsulated $\left[\mathrm{H}_{6} \mathbf{L}^{\mathbf{1}}\right]^{6+}$ moiety (Figure 2). All the secondary amino nitrogen atoms $\mathrm{N} 2$, N3, N5, N6, N7 and N8, from all three strands of the cryptand moiety are protonated, which is evident by the comparatively longer $\mathrm{C}-\mathrm{N}$ bond distances of these nitrogen atoms with the neighboring carbons (Table 1).

The encapsulated perchlorate is involved in two $\mathrm{N}-\mathrm{H} \cdots \mathrm{O}$ and five $\mathrm{O}-\mathrm{H} \cdots \mathrm{O}$ hydrogen bonding interactions with the protonated amino hydrogen atoms and lattice water molecules, respectively, as depicted in Figure 3. Thus, the perchlorate oxygen $\mathrm{O} 1$ is involved in two weak intermolecular hydrogen bonds $\mathrm{N}-\mathrm{H} \cdots \mathrm{O}$ with amino hydrogen atoms $\mathrm{H} 3 \mathrm{D}$ and $\mathrm{H} 8 \mathrm{D}$ of the protonated nitrogens ( $\mathrm{N} 3$ and $\mathrm{N} 8$ ) of the cryptand with $\mathrm{N} \cdots \mathrm{O}$ distances of $\mathrm{N} 3 \cdots \mathrm{O} 1=3.018(9) \AA$ and $\mathrm{N} 8 \cdots \mathrm{O} 1=3.146(8)$ $\AA$, and $\mathrm{N}-\mathrm{H} \cdots \mathrm{O}$ angles $<\mathrm{N} 3-\mathrm{H} 3 \mathrm{D} \cdots \mathrm{O} 1=118^{\circ}$ and $<\mathrm{N} 8-\mathrm{H} 8 \mathrm{D} \cdots \mathrm{O} 1=137^{\circ}$, respectively. The lattice water molecules also play a vital role in anchoring the $\mathrm{ClO}_{4}{ }^{-}$ion
Table 1: Selected non-bonded distances $(\AA)$ of complex 1.

$$
\mathrm{N} \cdots \mathrm{N} \text { Distance }[\AA]
$$

$\begin{array}{cl}\mathrm{N} 2 \cdots \mathrm{C} 2 & 1.494(8) \\ \mathrm{N} 2 \cdots \mathrm{C} 3 & 1.508(8) \\ \mathrm{N} 3 \cdots \mathrm{C} 10 & 1.484(9) \\ \mathrm{N} 3 \cdots \mathrm{C} 11 & 1.485(9) \\ \mathrm{N} 5 \cdots \mathrm{C} 14 & 1.502(8) \\ \mathrm{N} 5 \cdots \mathrm{C} 15 & 1.502(8) \\ \mathrm{N} 6 \cdots \mathrm{C} 22 & 1.493(8) \\ \mathrm{N} 6 \cdots \mathrm{C} 23 & 1.505(8) \\ \mathrm{N} 7 \cdots \mathrm{C} 26 & 1.489(8) \\ \mathrm{N} 7 \cdots \mathrm{C} 27 & 1.497(3) \\ \mathrm{N} 8 \cdots \mathrm{C} 34 & 1.497(8) \\ \mathrm{N} 8 \cdots \mathrm{C} 35 & 1.491(8)\end{array}$

inside the flexible hexaprotonated cryptand moiety. Five lattice water molecules $\mathrm{O} 25, \mathrm{O} 26, \mathrm{O} 27, \mathrm{O} 28$ and $\mathrm{O} 29$, which act as donors and are involved in strong $\mathrm{O}-\mathrm{H} \cdots \mathrm{O}$ hydrogen bonds with the encapsulated perchlorate oxygen atoms fasten the anion inside the cryptand moiety. All of these five water molecules act as acceptors and are oriented outside the cryptand leading to

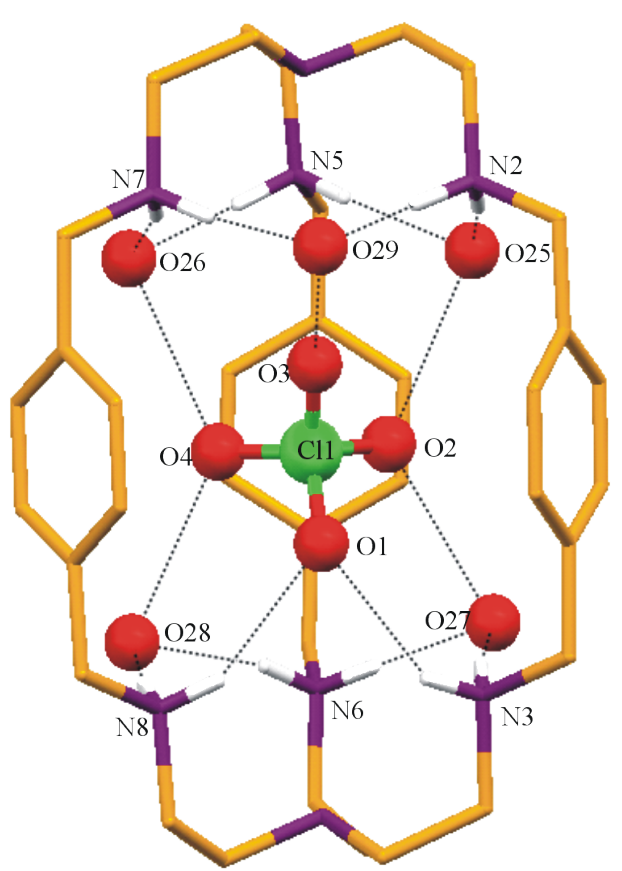

(a)

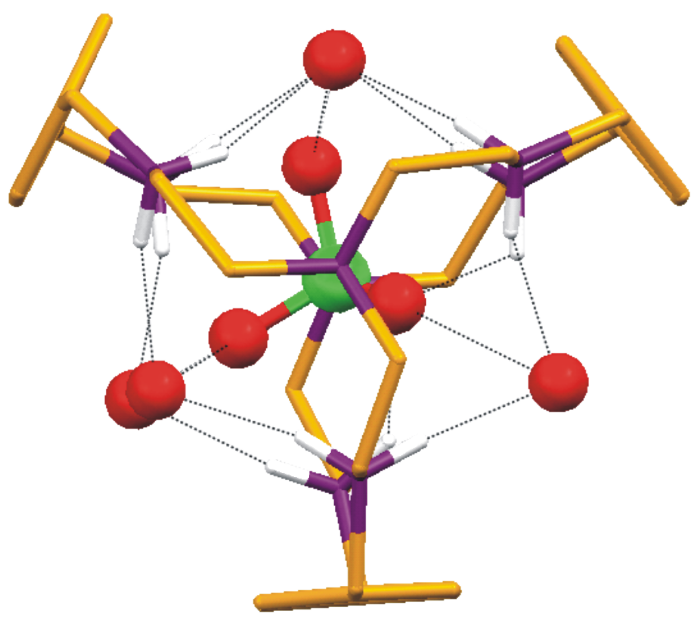

(b)

Figure 3: (a) Mercury diagram depicting the interactions of the encapsulated $\mathrm{ClO}_{4}{ }^{-}$within the $\left[\mathrm{H}_{6} \mathrm{~L}^{1}\right]^{6+}$ and the surrounding water molecules. (b) Mercury diagram depicting the interactions of the encapsulated $\mathrm{ClO}_{4}^{-}$within the hexaprotonated tere-cryptand moiety and the surrounding water molecules viewed down the bridgehead nitrogen atoms. Hydrogen atoms other than acidic, external perchlorates and lattice water molecules are omitted for clarity. 
good hydrogen bonding via $\mathrm{N}-\mathrm{H} \cdots \mathrm{O}$ with the protonated secondary amino hydrogen atoms (Table 2).

Table 2: Selected hydrogen-bond lengths $(\AA)$ and bond angles $\left({ }^{\circ}\right)$ of complex 1 .

\begin{tabular}{|c|c|c|c|c|}
\hline $\mathrm{D}-\mathrm{H} \cdots \mathrm{A}$ & $\begin{array}{l}\text { D-H } \\
{[\AA]}\end{array}$ & $\begin{array}{l}\mathrm{H} \cdots \mathrm{A} \\
[\AA]]\end{array}$ & $\mathrm{D} \cdots \mathrm{A}[\AA]$ & $\mathrm{D}-\mathrm{H} \cdots \mathrm{A}\left[{ }^{\circ}\right]$ \\
\hline $\mathrm{N} 2-\mathrm{H} 2 \mathrm{C} \cdots \mathrm{O} 25$ & 0.92 & 1.90 & $2.818(7)$ & 172 \\
\hline N5-H5C $\cdots \mathrm{O} 25$ & 0.92 & 1.98 & $2.855(7)$ & 159 \\
\hline N5-H5D $\cdots \mathrm{O} 26$ & 0.92 & 1.97 & $2.865(7)$ & 163 \\
\hline N7-H7D $\cdots O 26$ & 0.92 & 2.03 & $2.929(7)$ & 167 \\
\hline $\mathrm{N} 3-\mathrm{H} 3 \mathrm{C} \cdots \mathrm{O} 27$ & 0.92 & 1.96 & $2.869(9)$ & 168 \\
\hline $\mathrm{N} 6-\mathrm{H} 6 \mathrm{D} \cdots \mathrm{O} 27$ & 0.92 & 1.96 & $2.845(8)$ & 179 \\
\hline N6-H6C $\cdots O 28$ & 0.92 & 1.96 & $2.848(7)$ & 162 \\
\hline N8-H8D $\cdots \mathrm{O} 28$ & 0.92 & 1.98 & $2.897(9)$ & 172 \\
\hline $\mathrm{N} 2-\mathrm{H} 2 \mathrm{D} \cdots \mathrm{O} 29$ & 0.92 & 2.04 & $2.909(8)$ & 158 \\
\hline N7-H7C $\cdots$ O29 & 0.92 & 1.93 & $2.840(8)$ & 170 \\
\hline
\end{tabular}

The weaker intermolecular $\mathrm{N}-\mathrm{H} \cdots \mathrm{O}$ hydrogen bonds between the encapsulated perchlorate oxygen $\mathrm{O} 1$ and the $\left[\mathrm{H}_{6} \mathbf{L}^{1}\right]^{6+}$ moiety could be attributed to the involvement of H3D and H8D (at the protonated secondary amine sites of the cryptand) via strong intermolecular $\mathrm{N}-\mathrm{H} \cdots \mathrm{O}$ hydrogen bonding with the oxygen atom (O5) of lattice perchlorate (Table 3 ).

$\begin{aligned} & \text { Table 3: Selected hydrogen-bond lengths }(\AA) \text { and bond angles }\left({ }^{\circ}\right) \text { of } \\
& \text { complex 1. }\end{aligned}$
\begin{tabular}{lllll}
$\mathrm{D}-\mathrm{H} \cdots \mathrm{A}$ & $\begin{array}{l}\mathrm{D}-\mathrm{H} \\
{[\AA]}\end{array}$ & $\begin{array}{l}\mathrm{H} \cdots \mathrm{A} \\
{[\AA]}\end{array}$ & $\mathrm{D} \cdots \mathrm{A}[\AA]$ & $\mathrm{D}-\mathrm{H} \cdots \mathrm{A}\left[^{\circ}\right]$ \\
\hline $\mathrm{N} 3-\mathrm{H} 3 \mathrm{D} \cdots \mathrm{O}^{\mathrm{a}}$ & 0.92 & 2.04 & $2.932(9)$ & 163 \\
$\mathrm{~N} 8-\mathrm{H} 8 \mathrm{D} \cdots \mathrm{O}^{\mathrm{a}}$ & 0.92 & 2.26 & $3.063(8)$ & 146 \\
\hline
\end{tabular}

a $-x,-1 / 2+y, 1 / 2-z$.

Even though the data were collected at $100 \mathrm{~K}$, hydrogen atoms of the water molecules could not be located from the difference Fourier map, the interaction of these five water molecules are positioned near to the protonated amino nitrogen atoms via $\mathrm{N}-\mathrm{H} \cdots \mathrm{O}$ hydrogen bonds. All five water molecules are further involved in strong $\mathrm{O} \cdots \mathrm{O}$ contact with the perchlorate oxygen atoms $\mathrm{O} 2, \mathrm{O} 3$ and $\mathrm{O} 4$ whereas perchlorate oxygen atom $\mathrm{O} 1$ binds with protonated secondary amino nitrogen atoms through two weak $\mathrm{N}-\mathrm{H} \cdots \mathrm{O}$ hydrogen bonds which fix the $\mathrm{ClO}_{4}{ }^{-}$inside the protonated cryptand moiety. As mentioned above, $\mathrm{O} 1$ of the $\mathrm{ClO}_{4}{ }^{-}$is involved only in two weak $\mathrm{N}-\mathrm{H} \cdots \mathrm{O}$ hydrogen bonds with the amino nitrogen atoms, whereas $\mathrm{O} 2$ makes short contact with $\mathrm{O} 25$ and $\mathrm{O} 27$ at distances of 2.815, and $2.804 \AA$, O3 with O29 at a distance of $2.806 \AA$ and O4 with O26, and O28 at distances of 2.861 and $2.901 \AA$, respectively. In fact, water molecules act as donors to fix the anion inside the cavity. The concomitant effect of the weak $\mathrm{N}-\mathrm{H} \cdots \mathrm{O}$ hydrogen bonds by the hexaprotonated cryptand moiety and the orientation of the water molecules surrounding the protonated secondary amine followed by their short contacts with the other $\mathrm{ClO}_{4}{ }^{-}$ions pave way for the encapsulation of $\mathrm{ClO}_{4}{ }^{-}$in the cryptand cavity. Further, in $\left[\mathrm{H}_{6} \mathbf{L}^{\mathbf{1}}\right]^{6+}$ moiety of $\mathbf{1}$, the distances between any two of the secondary nitrogen atoms differ marginally in the two sets of tren cavities (N1N2N5N7) and (N3N4N6N8) (Table 4). This indicates that 3 -fold symmetry about the axis passing through N1 and N4 is present in the solid state. The Cl1 of encapsulated perchlorate is sitting within the bridgehead plane $(\mathrm{N} 1$ and $\mathrm{N} 4)$ and the $\mathrm{C} 11$ is placed closer to $\mathrm{N} 4(\mathrm{C} 11 \cdots \mathrm{N} 4=$ $4.813 \AA$ ) compared to the other bridgehead nitrogen $\mathrm{N} 1$ $(\mathrm{C} 11 \cdots \mathrm{N} 1=5.037 \AA)$. The distance between the bridgehead nitrogen atoms in $\mathbf{1}$ is $1.245 \AA$ shorter than the distance observed in the free cryptand $\mathbf{L}^{\mathbf{1}}$ (11.095 $\AA$ ) but the distance in complex 1 is $3.364 \AA$ longer than that of the monotopic bromide complex of $\mathbf{L}^{1}$ and only $0.527 \AA$ smaller than the ditopic bromide and water in $\left[\mathrm{H}_{6} \mathbf{L}^{1}\right]^{6+}$ complex reported recently $[10$, 11]. This observation suggests that depending upon guest(s), the cavity dimension of hexaprotonated $\mathbf{L}^{\mathbf{1}}$ could change abruptly indicating the highly flexible nature of $\mathbf{L}^{\mathbf{1}}$ in its hexaprotonated state.

\begin{tabular}{|c|c|}
\hline \multicolumn{2}{|c|}{$\mathrm{N} \cdots \mathrm{N}$ Distance $[\AA]]$} \\
\hline N2 $\cdots N 5$ & 4.530 \\
\hline $\mathrm{N} 2 \cdots \mathrm{N} 7$ & 4.385 \\
\hline N5 $\cdots$ N7 & 4.548 \\
\hline N3 $\cdots N 6$ & 4.529 \\
\hline N3 $\cdots N 8$ & 4.427 \\
\hline N6 $\cdots \mathrm{N} 8$ & 4.474 \\
\hline
\end{tabular}

Description of the Crystal Structure, $\left[\left(\mathrm{H}_{8} \mathbf{L}^{\mathbf{1}}\right)^{8+}\left(\mathrm{HSO}_{4}{ }^{-}\right)\right] 7\left(\mathrm{HSO}_{4}{ }^{-}\right) \cdot 3 \mathrm{H}_{2} \mathrm{O} \cdot \mathrm{CH}_{3} \mathrm{OH}$ (2). In this complex octaprotonated cryptand moiety acts as a cation and the eight $\left[\mathrm{HSO}_{4}\right]^{-}$anions present compensate the charge. Three molecules of water and one molecule of methanol are present in the lattice. The ORTEP diagram of the $\left[\mathrm{H}_{8} \mathbf{L}^{\mathbf{1}}\right]^{8+}$ moiety with the encapsulated $\mathrm{HSO}_{4}{ }^{-}$is depicted in Figure 4. The sulfur atom $\mathrm{S} 1$ of the encapsulated $\mathrm{HSO}_{4}{ }^{-}$deviates by $0.202 \AA$ with respect to the plane containing the protonated apical nitrogen atoms $\mathrm{N} 1$ and $\mathrm{N} 4$. In solid state $\left[\mathrm{H}_{8} \mathbf{L}^{1}\right]^{8+}$ has also an endo-endo conformation with a distance of $7.758 \AA$ between two bridgehead nitrogen atoms (N1 and N4) and the window between three phenyl rings ranges from $8.099 \AA$ to $8.403 \AA$ (measured by the centroid of the phenyl distance) with an average window of $8.255 \AA$ indicating the near spherical nature of the hydrogen 


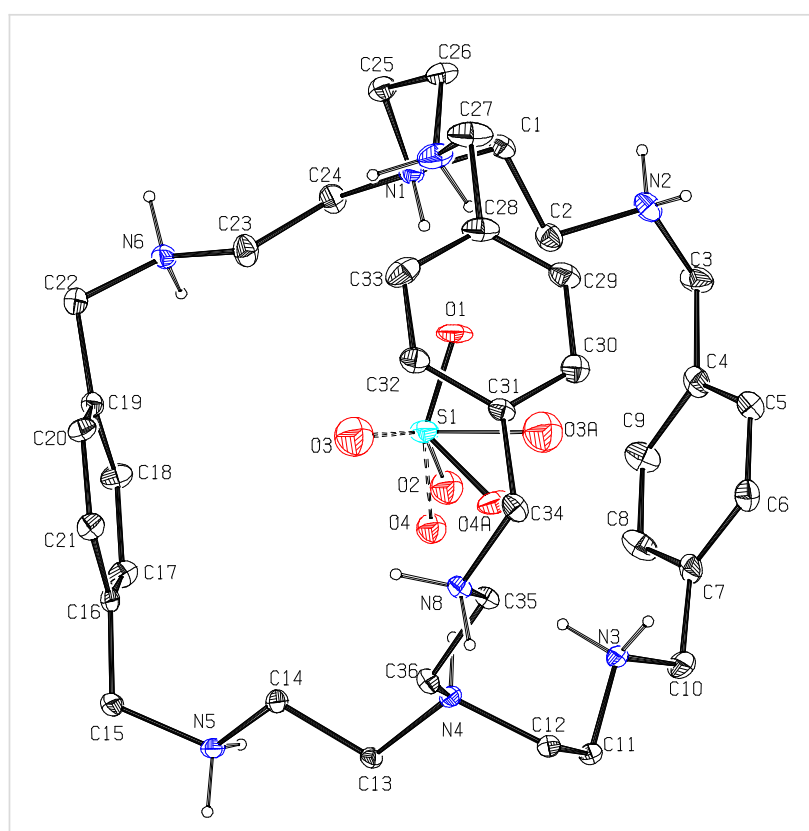

Figure 4: ORTEP diagram with atom numbering scheme depicting the octaprotonated $\mathrm{L}^{1}$ with disordered $\mathrm{HSO}_{4}{ }^{-}$monoanion inside the cavity (25\% probability factor for the thermal ellipsoids and only hydrogen atoms attached to the amino nitrogens are shown in the figure for clarity).

sulfate encapsulated $\left[\mathrm{H}_{8} \mathbf{L}^{\mathbf{1}}\right]^{8+}$ moiety. The bridgehead nitrogen atoms distance in complex 2 is $2.092 \AA$ smaller than that in complex 1 although in both cases recognition of oxyanion is monotopic in nature. This difference in complexes $\mathbf{1}$ and $\mathbf{2}$ could be due to the different degree of protonation. In fact our recent study on iodide encapsulation by $\left[\mathrm{H}_{8} \mathbf{L}^{1}\right]^{8+}$ moiety shows that the bridgehead nitrogen distance in octaprotonated $\mathbf{L}^{\mathbf{1}}$ is $6.925 \AA$ closer to the value observed in case of 2 [13]. The relatively higher value in case of complex 2 compared with the iodide encapsulated octaprotonated $\mathbf{L}^{\mathbf{1}}$ can be attributed to the polyatomic nature of $\mathrm{HSO}_{4}{ }^{-}$and flexible nature of the $\left[\mathrm{H}_{8} \mathbf{L}^{1}\right]^{8+}$ moiety. The sulfur atom $\mathrm{S} 1$ of the encapsulated $\mathrm{HSO}_{4}{ }^{-}$is located at distance of $3.92 \AA$ and $3.85 \AA$ from N1 and N4, respectively where $\mathrm{N} 4$ is slightly closer to $\mathrm{S} 1$. In $\left[\mathrm{H}_{8} \mathbf{L}^{\mathbf{1}}\right]^{8+}$ the distances between any two of the secondary nitrogen atoms differ in the two sets of N4 cavities (N1N2N6N7) and (N3N4N5N8) in the cryptand (Table 5). This indicates that the

Table 5: Selected non-bonded distance $(\AA)$ of complex 2.

$$
\mathrm{N} \cdots \mathrm{N} \text { Distance }[\AA]
$$

$\begin{array}{ll}\mathrm{N} 2 \cdots \mathrm{N} 6 & 6.548 \\ \mathrm{~N} 2 \cdots \mathrm{N} 7 & 5.791 \\ \mathrm{~N} 6 \cdots \mathrm{N} 7 & 5.809 \\ \mathrm{~N} 3 \cdots \mathrm{N} 5 & 5.732 \\ \mathrm{~N} 3 \cdots \mathrm{N} 8 & 6.078 \\ \mathrm{~N} 5 \cdots \mathrm{N} 8 & 6.588\end{array}$

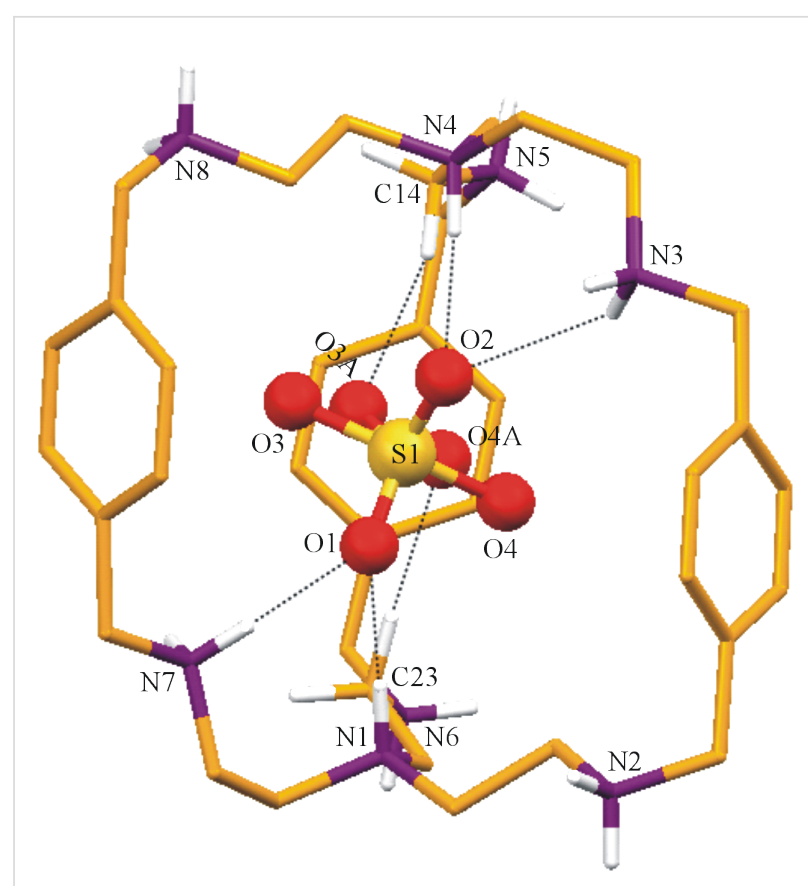

Figure 5: Mercury diagram depicting the encapsulation of disordered hydrogen sulfate in the cavity of $\left[\mathrm{H}_{8} \mathrm{~L}^{1}\right]^{8+}$ through various hydrogen bonding interactions.

3-fold symmetry about the axis passing through $\mathrm{N} 1$ and $\mathrm{N} 4$ is lost in the solid state.

Figure 5 represents the interaction of the $\left[\mathrm{H}_{8} \mathbf{L}^{1}\right]^{8+}$ receptor with the encapsulated disordered hydrogen sulfate. The anion is "glued" inside the receptor by two $\mathrm{C}-\mathrm{H} \cdots \mathrm{O}$ hydrogen bonds between the methylene hydrogen atoms (H14A, H23B) with the disordered oxygen atoms $\mathrm{O} 3 \mathrm{~A}$ and $\mathrm{O} 4 \mathrm{~A}$, respectively, and four $\mathrm{N}-\mathrm{H} \cdots \mathrm{O}$ contacts involving the both the protonated apical hydrogen atoms (H1D, H4D) and the hydrogen atoms (H3C and $\mathrm{H} 7 \mathrm{D}$ ) of protonated secondary amino nitrogen with $\mathrm{O} 1$ and $\mathrm{O} 2$ as acceptors each make two hydrogen bonds. Details of these intermolecular contacts are given in Table 6 .

Table 6: Selected hydrogen-bond lengths $(\AA)$ and bond angles $\left({ }^{\circ}\right)$ of complex 2 .

\begin{tabular}{|c|c|c|c|c|}
\hline $\mathrm{D}-\mathrm{H} \cdots \mathrm{A}$ & $\begin{array}{l}\text { D-H } \\
{[\AA \AA]}\end{array}$ & $\begin{array}{l}\mathrm{H} \cdots \mathrm{A} \\
[\AA]]\end{array}$ & $\mathrm{D} \cdots \mathrm{A}[\AA]$ & $\mathrm{D}-\mathrm{H} \cdots \mathrm{A}\left[{ }^{\circ}\right]$ \\
\hline $\mathrm{N} 1-\mathrm{H} 1 \mathrm{D} \cdots \mathrm{O} 1$ & 0.91 & 1.90 & $2.809(7)$ & 178 \\
\hline $\mathrm{N} 4-\mathrm{H} 4 \mathrm{D} \cdots \mathrm{O} 2$ & 0.91 & 2.02 & $2.896(7)$ & 162 \\
\hline $\mathrm{N} 3-\mathrm{H} 3 \mathrm{C} \cdots \mathrm{O} 2$ & 0.90 & 2.35 & $2.931(8)$ & 123 \\
\hline 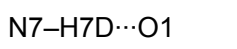 & 0.90 & 2.06 & $2.826(10)$ & 142 \\
\hline $\mathrm{C} 14-\mathrm{H} 14 \mathrm{~A} \cdots \mathrm{O} \mathrm{A}$ & 0.97 & 2.43 & $3.360(2)$ & 160 \\
\hline $\mathrm{C} 23-\mathrm{H} 23 \mathrm{~B} \cdots \mathrm{O} 4 \mathrm{~A}$ & 0.97 & 2.37 & $3.320(17)$ & 167 \\
\hline
\end{tabular}


Figure 6 represents the additional interactions of the ammonium hydrogen atoms with the surrounding anions and water molecules. It is observed that with the exception of the apical amino hydrogen atoms all others are involved in $\mathrm{N}-\mathrm{H} \cdots \mathrm{O}$ interactions with the lattice $\mathrm{HSO}_{4}{ }^{-}$or $\mathrm{O} 32$ of the water molecules. Thus, hydrogen atoms attached to N5 and N8 are involved in three contacts; one with water oxygen $\mathrm{O} 32$ and the other two with the oxygen atoms of $\mathrm{HSO}_{4}^{-}(\mathrm{O} 8, \mathrm{O} 10$ for $\mathrm{N} 5$ and $\mathrm{O} 10$, $\mathrm{O} 21$ for $\mathrm{N} 8$ ). The rest of the ammonium hydrogen atoms are also involved in effective $\mathrm{N}-\mathrm{H} \cdots \mathrm{O}$ contacts with the hydrogen sulfate as depicted in Figure 6.

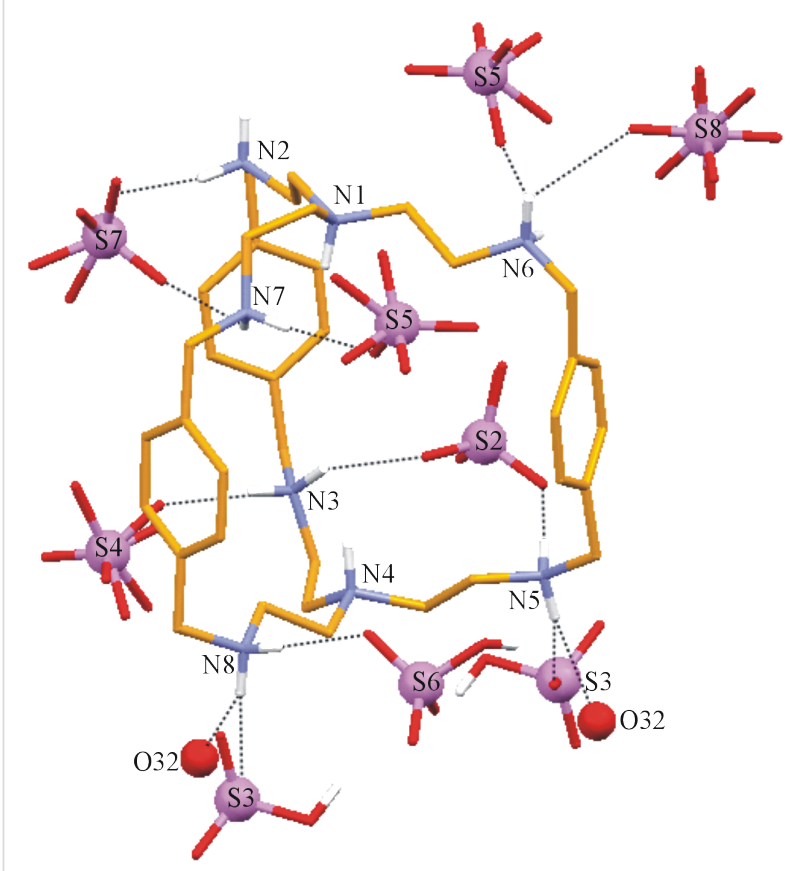

Figure 6: Interactions of the protonated amino nitrogen centers of the $\left[\mathrm{H}_{8} \mathrm{~L}^{1}\right]^{8+}$ moiety with the surrounding hydrogen sulfate and water molecules.

Description of the Crystal Structure, $\left[\left(\mathrm{H}_{8} \mathbf{L}^{\mathbf{1}}\right)^{8+}\left(\mathrm{HSiF}_{6}{ }^{-}\right)\right] 3\left(\mathrm{SiF}_{6}{ }^{2-}\right) \cdot\left(\mathrm{HSiF}_{6}{ }^{-}\right) \cdot 15 \mathrm{H}_{2} \mathrm{O}(\mathbf{3})$. Silicon hexafluoride salt of $\mathbf{L}^{\mathbf{1}}$ is obtained on reaction between $\mathbf{L}^{\mathbf{1}}$ and $\mathrm{HF}$, apparently as a result of glass corrosion. The salt $\left[\mathrm{H}_{8} \mathbf{L}^{\mathbf{1}}\right]^{8+}$ has three molecules of $\mathrm{SiF}_{6}{ }^{2-}$, and two molecules of $\mathrm{HSiF}_{6}{ }^{-}$ anions to compensate the charge and fifteen water molecules as solvent of crystallization. The ORTEP diagram of the octaprotonated cryptand with the encapsulated disordered $\mathrm{HSiF}_{6}{ }^{-}$ monoanion is depicted in Figure 7 and the various interactions of the disordered $\mathrm{HSiF}_{6}{ }^{-}$monoanion with the host molecule is depicted in Figure 8. Thus, hydrogen atoms $\mathrm{H} 1$ and $\mathrm{H} 4$ attached to the apical nitrogen $\mathrm{N} 1$ and $\mathrm{N} 4$ form $\mathrm{N}-\mathrm{H} \cdots \mathrm{F}$ hydrogen bonds (one and three) with F1 and F2A, F3, F4, respectively. Both $\mathrm{F} 2 \mathrm{~A}$ and $\mathrm{F} 3$ are involved in an additional $\mathrm{N}-\mathrm{H} \cdots \mathrm{F}$ hydrogen bonding interaction with the protonated secondary amino hydrogen atoms $\mathrm{H} 3 \mathrm{D}$ and $\mathrm{H} 6 \mathrm{D}$ attached to $\mathrm{N} 3$ and N6, respectively. $\mathrm{F} 1$ of the disordered encapsulated $\mathrm{HSiF}_{6}{ }^{-}$is involved in intermolecular $\mathrm{C}-\mathrm{H} \cdots \mathrm{F}$ contacts with the methylenic hydrogen atom $\mathrm{H} 14 \mathrm{~B}$, while $\mathrm{H} 26 \mathrm{~B}$ of the methylene hydrogen attached to C26 forms bifurcated weak $\mathrm{C}-\mathrm{H} \cdots \mathrm{F}$ hydrogen bonds [35-38] with $\mathrm{F} 5$ and $\mathrm{F} 6$ in fixing the monoanion inside the cryptand moiety (Figure 8). Details of these hydrogen bonding interactions are given in Table 7. The $\mathrm{C}-\mathrm{N}$ distances involving the amino nitrogen range from 1.49 to $1.53 \AA$ clearly indicate the octa protonation of the cryptand moiety including both the apical nitrogen atoms and are well within the range of earlier reported values [13]. Protonation of the $\mathrm{SiF}_{6}{ }^{2-}$ is clearly reflected in the case of $\mathrm{Si} 1$ and $\mathrm{Si} 3$ by the longer $\mathrm{Si}-\mathrm{F}$ distances: $\operatorname{Si}(1)-F(4)=1.725(5) \AA$, and $\operatorname{Si}(3)-F(14)=1.742(6) \AA$, indicating that the encapsulated anion is $\mathrm{HSiF}_{6}^{-}$. The Sil of encapsulated $\mathrm{HSiF}_{6}{ }^{-}$monoanion is slightly above by $0.89 \AA$ from the plane involving the apical protonated nitrogen atoms with N1-Si1 distance of $3.854 \AA$ and a N4-Si1 distance of $3.739 \AA$, respectively. In the solid state $\left[\mathrm{H}_{8} \mathbf{L}^{\mathbf{1}}\right]^{8+}$ has also an endo-endo conformation with a distance of $7.571 \AA$ between the two bridgehead nitrogen atoms ( 11 and N4) and the window between three phenyl rings ranges from $8.246 \AA$ to $8.368 \AA$ (measured by the centroid of phenyl distance) with an average window of $8.346 \AA$ which is very close to the distances observed in complex $\mathbf{2}$ where $\mathbf{L}^{\mathbf{1}}$ is also in octaprotonated state.

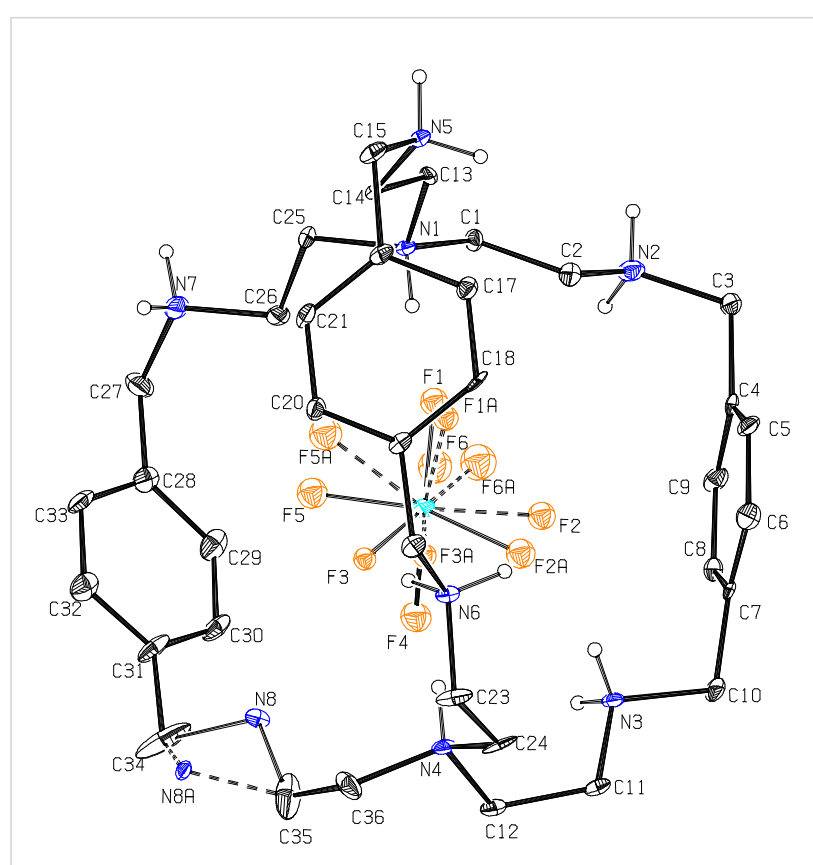

Figure 7: ORTEP diagram depicting the octaprotonated $\left[\mathrm{H}_{8} \mathrm{~L}^{1}\right]^{8+}$ moiety with the encapsulated disordered $\mathrm{HSiF}_{6}{ }^{-}$monoanion with atom numbering scheme ( $25 \%$ probability factor for the thermal ellipsoids and only hydrogen atoms attached to the amino nitrogens are shown for clarity). 


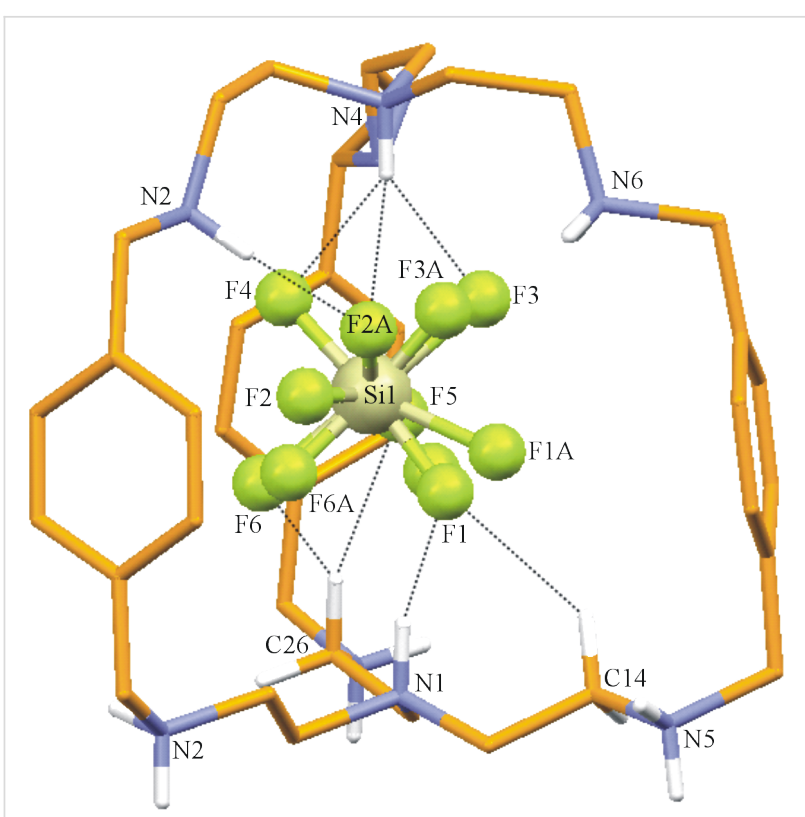

Figure 8: Mercury diagram depicting the encapsulation of the disordered $\mathrm{HSiF}_{6}{ }^{-}$inside the $\left[\mathrm{H}_{8} \mathrm{~L}^{1}\right]^{8+}$ moiety along with various hydrogen bonding interactions. Only hydrogen atoms having interactions with encapsulated anion are shown for clarity.

\begin{tabular}{|c|c|c|c|c|}
\hline $\mathrm{D}-\mathrm{H} \cdots \mathrm{A}$ & $\begin{array}{l}\text { D-H } \\
[\AA]]\end{array}$ & $\begin{array}{l}\mathrm{H} \cdots \mathrm{A} \\
{[\AA]}\end{array}$ & $\mathrm{D} \cdots \mathrm{A}[\AA]]$ & $\mathrm{D}-\mathrm{H} \cdots \mathrm{A}\left[{ }^{\circ}\right]$ \\
\hline $\mathrm{N} 1-\mathrm{H} \cdots \mathrm{F} 1$ & 0.91 & 1.88 & $2.756(9)$ & 161 \\
\hline N3-H3D $\cdots F 2 A$ & 0.90 & 1.92 & $2.789(11)$ & 163 \\
\hline $\mathrm{N} 4-\mathrm{H} 4 \cdots \mathrm{F} 2 \mathrm{~A}$ & 0.91 & 2.27 & $3.053(11)$ & 143 \\
\hline $\mathrm{N} 4-\mathrm{H} 4 \cdots \mathrm{F} 3$ & 0.91 & 2.12 & $2.904(10)$ & 143 \\
\hline $\mathrm{N} 4-\mathrm{H} 4 \cdots \mathrm{F} 4$ & 0.91 & 2.25 & $2.988(8)$ & 137 \\
\hline $\mathrm{N} 6-\mathrm{H} 6 \mathrm{D} \cdots \mathrm{F} 3$ & 0.90 & 1.86 & $2.726(8)$ & 160 \\
\hline $\mathrm{C} 14-\mathrm{H} 14 \mathrm{~B} \cdots \mathrm{F} 1$ & 0.97 & 2.41 & $3.190(10)$ & 137 \\
\hline $\mathrm{C} 26-\mathrm{H} 26 \mathrm{~B} \cdots \mathrm{F} 5$ & 0.97 & 2.39 & $3.318(14)$ & 161 \\
\hline $\mathrm{C} 26-\mathrm{H} 26 \mathrm{~B} \cdots \mathrm{F} 6$ & 0.97 & 2.45 & $3.180(14)$ & 132 \\
\hline
\end{tabular}

Figure 9 represents the interaction of the protonated amino nitrogen atoms with the molecules surrounding the moiety. As depicted in the figure the hydrogen atoms of protonated secondary nitrogen centers are involved in strong $\mathrm{N}-\mathrm{H} \cdots \mathrm{F}$ and $\mathrm{N}-\mathrm{H} \cdots \mathrm{O}$ hydrogen bonds with the external anions and lattice water molecules.

\section{Conclusions}

The structural results for the interaction of polyatomic anions with the ligand $\mathbf{L}^{\mathbf{1}}$ in its hexa and octa protonated states show some interesting results. The structures clearly illustrate the effect of hexaprotonation and octaprotonation on the encapsulation of different anions. Upon a higher degree of protonation

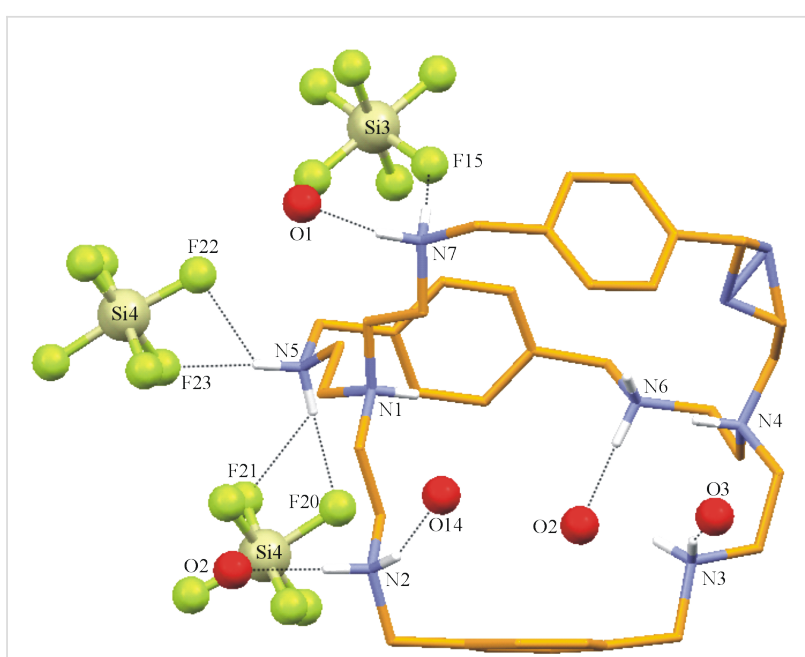

Figure 9: Mercury diagram depicting the interaction of the $\left[\mathrm{H}_{8} \mathrm{~L}^{1}\right]^{8+}$ with the surrounding molecules via $\mathrm{N}-\mathrm{H} \cdots \mathrm{F}$ and $\mathrm{N}-\mathrm{H} \cdots \mathrm{O}$ hydrogen bonds.

(hexa and octa) distribution of positive charge over the receptor increases which makes the cavity more electrophilic. Different degrees of protonation also change the overall conformation (ellipsoid and near spherical), which allows encapsulation of anions like perchlorate, hydrogen sulfate and hexafluorosilicate inside the receptor. Furthermore, these results indeed show that $\mathbf{L}^{\mathbf{1}}$ is also a potential receptor for bigger polyatomic anions like perchlorate and hydrogen sulfate.

\section{Supporting Information}

Experimental procedures, characterization data and copies of spectra ( ${ }^{1} \mathrm{H}$ NMR and HRMS) of complexes 1, 2, and $\mathbf{3}$ as well as crystallographic data and tables of hydrogen bonding parameters of complexes 1, 2, and $\mathbf{3}$ are provided.

\section{Supporting Information File 1}

Experimental and analytical data.

[http://www.beilstein-journals.org/bjoc/content/ supplementary/1860-5397-5-41-S1.doc]

\section{Acknowledgments}

P.G. gratefully acknowledges the Department of Science and Technology (DST), New Delhi, India for financial support. PSL would like to acknowledge CSIR, New Delhi, India for Senior Research Fellowship.

\section{References}

1. Bianchi, A.; Bowman-James, K.; García-España, E., Eds. Supramolecular Chemistry of Anions; Wiley-VCH: New York, 1997.

2. Coord. Chem. Rev. 2003, 240, 1-226. 
3. Atwood, J. L.; Steed, J. W. The Encyclopedia of Supramolecular Chemistry; Dekker: New York, 2004.

4. Coord. Chem. Rev. 2006, 250, 2917-3244.

5. Robinson, B. H.; Williams, G. R. Biochem. Biophys. Acta 1970, 216 , 63-70. doi:10.1016/0005-2728(70)90159-3

6. Kimura, E. Macrocyclic polyamines as biological cation and anion complexones - An application to calculi dissolution. In Topics in Current Chemistry; Springer: Berlin/Heidelberg, 1985; Vol. 128, pp 113-141.

7. He, J. H.; Quicocho, F. A. Science 1991, 251, 1479-1481. doi:10.1126/science.1900953

8. Barth, M. C.; Church, A. T. J. Geophys. Res. 1999, 104, 30231-30239. doi:10.1029/1999JD900809

9. Hossain, M. A.; Llinares, J. M.; Mason, S.; Morehouse, P.; Powell, D.; Bowman-James, K. Angew. Chem., Int. Ed. 2002, 41, 2335-2338. doi:10.1002/1521-3773(20020703)41:13<2335::AID-ANIE2335>3.0.CO ;2-3

10. Hossain, M. A.; Morehouse, P.; Powell, D.; Bowman-James, K. Inorg. Chem. 2005, 44, 2143-2149. doi:10.1021/ic048937e

11. Lakshminarayanan, P. S.; Kumar, D. K.; Ghosh, P. Inorg. Chem. 2005, 44, 7540-7546. doi:10.1021/ic051191f

12. Lakshminarayanan, P. S.; Suresh, E.; Ghosh, P. Angew. Chem., Int. Ed. 2006, 118, 3891-3895. doi:10.1002/ange.200600254

13. Lakshminarayanan, P. S.; Ravikumar, I.; Suresh, E.; Ghosh, P. Cryst. Growth Des. 2008, 8, 2842-2852. doi:10.1021/cg701152v

14. Hossain, M. A.; Morehouse, P.; Powell, D.; Bowman-James, K. Inorg. Chem. 2005, 44, 2143-2149. doi:10.1021/ic048937e

15. Alcock, N. W.; Bowman-James, K.; Miler, C.; Berenguer, J. M. L. Private Communication 2005.

16. Mason, S.; Llinares, J. M.; Morton, M.; Clifford, T.; Bowman-James, K. J. Am. Chem. Soc. 2000, 122, 1814-1815. doi:10.1021/ja9939800

17. Menif, R.; Reibenspies, J.; Martell, A. E. Inorg. Chem. 1991, 30 , 3446-3454. doi:10.1021/ic00018a014

18. Mason, S.; Clifford, T.; Seib, L.; Kuczera, K.; Bowman-James, K. J. Am. Chem. Soc. 1998, 120, 8899-8900. doi:10.1021/ja9811593

19. Hynes, M. J.; Mauber, B.; McKee, V.; Town, R. M.; Nelson, J. J. Chem. Soc., Dalton Trans. 2000, 2853-2859. doi:10.1039/b003249m

20. Maubert, B. M.; Nelson, J.; McKee, V.; Town, R. M.; Pál, I. J. Chem. Soc., Dalton Trans. 2001, 1395-1397. doi:10.1039/b101832i

21. Nelson, J.; Nieuwenhuyzen, M.; Pál, I.; Town, R. M. Chem. Commun. 2002, 2266-2267. doi:10.1039/b207964j

22. Farrell, D.; Gloe, K.; Gloe, K.; Goretzki, G.; McKee, V.; Nelson, J.; Nieuwenhuyzen, M.; Pál, I.; Stephan, H.; Town, R. M.; Wichmann, K. Dalton Trans. 2003, 1961-1968. doi:10.1039/b210289g

23. Morgan, G.; McKee, V.; Nelson, J. J. Chem. Soc., Chem. Commun. 1995, 1649-1652. doi:10.1039/C39950001649

24. Kang, S. O.; Hossain, M. A.; Powell, D.; Bowman-James, K. Chem. Commun. 2005, 328-330. doi:10.1039/b411904e

25. McKee, V.; Morgan, G. G. Acta Crystallogr. 2003, C59, o150-o152. doi:10.1107/S0108270103002580

26. Yang, L.-Z.; Jiang, L.; Feng, X.-L.; Lu, T.-B. CrystEngComm 2008, 10 , 649-651. doi:10.1039/b717967g

27. Reyheller, C.; Kubik, S. Org. Lett. 2007, 9, 5271-5274. doi:10.1021/ol702386e

28. Hossain, M. A.; Llinares, J. M.; Powell, D.; Bowman-James, K. Inorg. Chem. 2001, 40, 2936-2937. doi:10.1021/ic015508x
29. Katayev, E. A.; Boev, N. V.; Khrustalev, V. N.; Ustynyuk, Y. A.; Tananaey, I. G.; Sessler, J. L. J. Org. Chem. 2007, 72, 2886-2896. doi:10.1021/jo0624849

30. Sessler, J. L.; Katayev, E.; Pantso, G. D.; Ustynyuk, Y. A. Chem. Commun. 2004, 1276-1277. doi:10.1039/b403665d

31. Sessler, J. L.; Katayev, E.; Pantos, G. D.; Scherbakov, P.; Reshetova, M. D.; Khrustalev, V. N.; Lynch, V. M.; Ustynyuk, Y. A. J. Am. Chem. Soc. 2005, 127, 11442-11446. doi:10.1021/ja0522938

32. Clifford, T.; Dnaby, A.; Llinares, J. M.; Mason, S.; Alcock, N. W.; Powell, D.; Aguilar, J. A.; Garcia-España, E.; Bowman-James, K. Inorg. Chem. 2001, 40, 4710-4720. doi:10.1021/ic010135I

33. McKee, V.; Nelson, J.; Town, R. M. Chem. Soc. Rev. 2003, 32, 309-325. doi:10.1039/b200672n

34. Ilioudis, C. A.; Tocher, D. A.; Steed, J. W. J. Am. Chem. Soc. 2004, 126, 12395-12402. doi:10.1021/ja047070g

35. Abouderbala, L. O.; Belcher, W. J.; Boutelle, M. G.; Cragg, P. J.; Steed, J. W.; Turner, D. R.; Wallace, K. J. Proc. Natl. Acad. Sci. U. S. A. 2002, 99, 5001-5006. doi:10.1073/pnas.082633299

36. Jeffery, G. A. An Introduction to Hydrogen Bonding; Oxford Univ. Press: Oxford, 1997.

37. Braga, D.; Grepioni, F.; Desiraju, G. R. Chem. Rev. 1998, 98, 1375-1405. doi:10.1021/cr960091b

38. Arya, P.; Channa, A.; Cragg, P. J.; Prince, P. D.; Steed, J. W. New J. Chem. 2002, 4, 440-447. doi:10.1039/b108522k

\section{License and Terms}

This is an Open Access article under the terms of the Creative Commons Attribution License (http://creativecommons.org/licenses/by/2.0), which permits unrestricted use, distribution, and reproduction in any medium, provided the original work is properly cited.

The license is subject to the Beilstein Journal of Organic Chemistry terms and conditions:

(http://www.beilstein-journals.org/bjoc)

The definitive version of this article is the electronic one which can be found at: doi:10.3762/bjoc. 5.41 